\title{
Effects of Prenatal Ethanol Exposure on Postnatal Growth and the Insulin-Like Growth Factor Axis
}

\author{
Sofía Aros $^{a}$ James L. Mills ${ }^{c} \quad$ Germán Iñiguez $^{b} \quad$ Alejandra Avila $^{b}$ Mary R. Conley ${ }^{c}$ \\ James Troendle ${ }^{c}$ Christopher Cox ${ }^{c}$ Fernando Cassorlab \\ ${ }^{a}$ Department of Pediatrics, Faculty of Medicine, University of Chile, San Borja Arriarán Clinical Hospital, and \\ ${ }^{b}$ Institute of Maternal and Child Research, Faculty of Medicine, University of Chile, Santiago, Chile; \\ 'Division of Epidemiology, Statistics and Prevention Research, Eunice Kennedy Shriver National Institute of \\ Child Health and Human Development, National Institutes of Health, Department of Health and Human Services, \\ Bethesda, Md., USA
}

\section{Key Words}

Fetal alcohol syndrome - Pregnancy - Alcohol abuse • Insulin-like growth factor I - Insulin-like growth factor II

\begin{abstract}
Aims: To study the effect of in-utero alcohol exposure on the insulin-like growth factor axis (IGF) and leptin during infancy and childhood, considering that exposed children may exhibit pre- and postnatal growth retardation. Methods: We prospectively identified heavily drinking pregnant women who consumed on average 4 or more drinks of ethanol per day ( $\geq 48 \mathrm{~g} /$ day) and assessed growth in 69 of their offspring and an unexposed control group of 83 children, measuring serum IGF-I (radioimmunoassay), IGF-II (immunoradiometric assay, IRMA), insulin-like growth factor-binding protein 3 (IGFBP-3) (IRMA) and leptin (IRMA) at 1 month and 1, 2, 3, 4, and 5 years of age. Results: IGF-II levels increased with age in both groups, but the rate of increase was significantly higher in exposed children, and levels were significantly higher in ethanol-exposed children at 3,4, and 5 years of age. In exposed children, IGF-I levels were higher at 3 and 4 years and leptin levels were significantly lower at 1 and 2 years. Exposed subjects showed a much lower correlation be-
\end{abstract}

tween IGF-I and growth parameters than unexposed subjects. Conclusion: Exposure to ethanol during pregnancy increases IGF-I and IGF-II and decreases leptin during early childhood. The increase in serum IGF-II concentrations in ethanol-exposed children suggests that this hormone should be explored as a potential marker for prenatal alcohol exposure.

Copyright $\odot 2010$ S. Karger AG, Basel

\section{Introduction}

Prenatal ethanol exposure may cause severe teratogenic effects on the human fetus. The spectrum of possible clinical manifestations due to consumption of alcohol during pregnancy is broad. Pre- and/or postnatal growth retardation is one of the main characteristics of the fetal alcohol syndrome (FAS) [1]. Human and animal studies show that ethanol exposure during pregnancy may interfere with weight gain and statural growth, both prenatally and postnatally $[2,3]$. In rats, a reduction in fetal body weight after alcohol intoxication that is directly related to the severity of the intoxication, and is not due to malnutrition has been documented [4]. The effects of

\section{KARGER}

(C) 2010 S. Karger AG, Basel

Fax +4161306 1234

E-Mail karger@karger.ch

www.karger.com
Accessible online at:

www.karger.com/hrp
James L. Mills, MD, MS

6100 Bldg. Room 7 B03. NICHD, NIH, DHHS

Bethesda, MD 20892 (USA)

Tel. +1 301496 5394, Fax +1 3014022084

E-Mail jamesmills@nih.gov 
prenatal alcohol exposure may be permanent, as evidenced by the Maternal Health Practices and Child Development Project that shows significant deficits in growth through 14 years [5]. Most of the studies show growth retardation in the offspring at birth and during infancy, whereas at older ages, growth retardation has been reported in some, but not in all studies [6].

The possible mechanisms that may cause growth retardation in ethanol-exposed fetuses are not clear but do not appear to be related to growth hormone (GH) or thyroid deficiency $[7,8]$. Ethanol exposure during pregnancy may influence growth by affecting insulin-like growth factors and insulin-like growth factor-binding proteins (IGF-IGFBP) concentrations. A report of 6 prepubertal short children with FAS showed that GH secretion was similar to that in short children born small for gestational age (SGA), and that the plasma concentrations of IGFI and IGFBP-3 were in the lower end of the normal range [9]. One study found increased GH levels and low IGF-I levels in newborns of ethanol-abusing women compared with infants of abstinent mothers [10], and a similar finding has been observed in some SGA infants [11]. In addition, a study in rodents demonstrates that chronic gestational exposure to ethanol alters gene expression of the insulin-IGF signaling pathways [12], and there is evidence for a possible effect of ethanol on the regulation of the GHRH/GH/IGF-I system, with reduced levels of IGFI, IGFBP-3 and elevated concentrations of IGF-II [13-15].

In adults, chronic ethanol consumption reduces circulating levels of IGF-I and increases IGFBP-1, probably by an effect in the liver [16]. In healthy adults, alcohol has an inhibitory effect on leptin secretion and this may be caused by a direct effect on adipocytes [17].

There is very limited information regarding linear growth and the insulin-like growth factor axis in humans who are heavily exposed to ethanol during gestation. We performed a prospective study of growth in children exposed to large quantities of ethanol in utero ( $\geq 48 \mathrm{~g} /$ day), examining the serum concentrations of IGF-I, IGF-II, IGFBP-3 and leptin during the first 5 years of life.

\section{Methods}

We prospectively identified 101 pregnant women who drank on average at least $48 \mathrm{~g}$ ( 4 drinks) of absolute ethanol per day. This definition is based upon the available literature, which indicates that an ethanol intake greater than $48 \mathrm{~g} /$ day may have deleterious consequences on the developing central nervous system of the fetus $[18,19]$. The study methods have been described in detail previously [20]. Briefly, at a primary care clinic which provides care for approximately $60 \%$ (290,000 inhabitants) of an unselected lower-middle class neighborhood of Santiago in Chile, we interviewed 9,628 pregnant women $(88.2 \%$ of those obtaining prenatal care) from August 1995 to July 2000. During the first prenatal visit, a specially trained social worker administered a standardized questionnaire which asked subtle questions about possible ethanol exposure. Subsequently, 887 of these women, who were identified as possible ethanol abusers, were evaluated with a home visit for more intensive investigation of their drinking patterns. The interviews contained questions about consumption of food, beverages, tobacco and drugs, especially alcohol. These interviews established the apparent duration of ethanol exposure and the pattern of drinking for each woman. Women were questioned about frequency of drinking and amount of each beverage consumed each time the woman drank using standard questions and standard drink sizes. The questions were carefully designed to minimize denial and guilt, differentiating the period prior to pregnancy and between the time before and after the woman knew she was pregnant. After the interview, the women were advised that drinking could be dangerous to the fetus and offered help at the facility's alcohol clinic. Women were then followed during pregnancy to assess any changes in drinking behavior. The nondrinking control subjects selected for the main study were followed during several years with repeated clinical evaluations, but they did not participate in the hormone study because requesting the mothers of the unexposed control children to allow us to take blood samples, in addition to requiring frequent follow-up for their babies, would have caused a serious noncompliance problem.

Therefore, to establish normal values of IGF-I, IGF-II, IGFBP-3 and leptin during the first 5 years of life in a Chilean population unexposed to alcohol during pregnancy, we studied a group of unexposed children who consisted of adequate-for-gestationalage (AGA) healthy children of normal height and weight, who were followed in two well-baby clinics and came from the same geographical area and socioeconomic group as the exposed group. The unexposed group was a cross-sectional sample except for a group of children who provided data at 1 and 2 years (enabling us to look at changes over that time period). These mothers were healthy, had regular prenatal care with normal pregnancies, and were selected because they did not drink ethanol during pregnancy. The data from these children were analyzed for the auxological and hormonal studies.

Birth anthropometry was performed on the exposed subjects by one observer (S.A.), during the first $24 \mathrm{~h}$ after birth, with an average of 5 repeated measurements of weight and length. Weight was obtained using a calibrated digital scale with an error of $10 \mathrm{~g}$ (Soehnle, Germany). Supine length was measured using an instrument consisting of a fixed board for the infant's head and a movable board allowing the feet to be placed perpendicular to the longitudinal axis of the infant. We defined SGA as newborns with birth weight below the 10th percentile for Chilean standards [21].

We collected data on the children exposed to ethanol during pregnancy and the unexposed, with the following protocol:

(1) Anthropometry: At birth, at 1 month, at 1 year and once a year until 5 years of age. During each evaluation, we performed 3-5 separate measurements of weight and height. Weight was measured using a manual scale with a 10-gram graduation (Seca, Germany). Up to 3 years of age, length was measured with the instrument described above, and after 3 years of age, height was 
measured using a Harpenden stadiometer (Holtain Limited, Crymych, UK). These measures were performed by one observer (A.A.).

(2) Hormone measurements: We determined the serum concentrations of IGF-I, IGF-II, IGFBP-3 and leptin in both ethanolexposed and unexposed children whose samples were collected at 1 month and at $1,2,3,4$, and 5 years of age.

This study was approved by the Institutional Review Boards of the University of Chile, San Borja Arriarán Hospital and National Institute of Child Health and Human Development, National Institutes of Health, and we obtained written informed consent from each mother.

Serum IGF-I levels were determined by radioimmunoassay [22]. The sensitivity of this assay is $5.0 \mathrm{ng} / \mathrm{ml}$, intra-assay CV is $8.6 \%$, and the inter-assay CV is $10.2 \%$. Serum IGFBP-3 and leptin concentrations were determined using a commercial immunoradiometric assay (Diagnostic System Laboratories, Webster, Tex., USA). The sensitivities of the assays are $0.1 \mathrm{mg} / \mathrm{l}$ and $0.1 \mathrm{ng} / \mathrm{ml}$, respectively; the intra-assay $\mathrm{CV}$ is $1.1 \%$, and the inter-assay $\mathrm{CV}$ is $1.8 \%$ for IGFBP-3, and the intra-assay CV is $4.6 \%$, and the interassay CV, $6.2 \%$ for leptin $[23,24]$. IGF-II serum concentrations were determined using a commercial IGF-II IRMA system (Diagnostic System Laboratories). The sensitivity of the assay is $10 \mathrm{ng} /$ $\mathrm{ml}$, intra-assay CV is $4.8 \%$ and the inter-assay CV is $7.9 \%$. Personnel performing the laboratory analysis were unaware of the status (exposed or unexposed) of the samples.

Comparisons between groups were made using Wilcoxon's rank-sum test. To compare the proportion of exposed infants who were SGA to the Chilean population, we used the exact test to compare the binomial proportion with a fixed value. To assess changes over time, a repeated-measures linear mixed model (PROC MIXED of SAS) was used that accounted for the correlated values on the same exposed children. This model allowed for differences by exposure group and gender as well as separate slopes against time for each exposure group and gender. Rank correlations were used to assess relationships between changes in $\mathrm{Z}$-score for height or weight from 1 year to 2 years of age and hormone levels. All comparisons were two-tailed. Analysis was carried out using SAS, version 9 and StatXact, version 4.

\section{Results}

Out of the original population of 101 ethanol-exposed children, we included in this study the 69 (35 boys and 34 girls) who had reasonably complete follow-up along with 83 unexposed children ( 50 boys and 33 girls). Three of the exposed children had FAS. Socio-demographic data were available for all women in the exposed group and a subset of women in the control group. The mean maternal ages were 24.7 (7.1 SD) and 26.7 (8.2 SD), respectively (not significantly different). In both the exposed and unexposed groups, the percentage of women under 20 and over 34 were the same: 30.4 and $23.5 \%$, respectively. Multiparas constituted $46.4 \%$ of the exposed group and $52.9 \%$ of the control group. All subjects (exposed and controls) were ethnically Chilean and belonged to the lower-middle class.

\section{Alcohol, Tobacco and Drug Use among Mothers}

The 69 mothers of these ethanol-exposed children drank at least 4 drinks or $48 \mathrm{~g}$ (or $2 \mathrm{oz}$ ) of alcohol per day during pregnancy. Six of them (8.7\%) drank only during the first trimester. Three women $(4.3 \%)$ were not able to say whether their consumption changed during pregnancy. Of the remaining 60 (87\%), 29 continued to drink at the same level throughout pregnancy and 31 pregnant women decreased their consumption during the pregnancy - most (27) in the second trimester. Data were available in the alcohol-exposed group on several other factors that might influence growth and hormone levels. There were 48 women in the exposed group who smoked during pregnancy (70\%) and 26 who used recreational drugs (38\%), principally marijuana (32\%) and cocaine or cocaine derivatives (16\%). By design, none of the control women used alcohol during pregnancy; of those who provided data, none used recreational drugs; and 11.8\% smoked.

We compared hormone levels in exposed children whose mothers used recreational drugs, smoked cigarettes, or decreased their alcohol consumption or stopped drinking during the second or third trimester of pregnancy with levels in children whose mothers did not. Hormone levels did not differ significantly (except for one comparison, leptin at 3 years was significantly higher in those who reduced drinking in the second trimester). Thus, smoking, changing drinking habits and use of recreational drugs did not produce a major effect on hormone levels. Information about drugs and tobacco use was not fully available in the control population, so this comparison could not be performed. We examined hormone levels by level of alcohol consumption after the woman knew that she was pregnant. Dichotomizing the population by the amount of alcohol consumed per week, those who were in the upper half did not have significantly different levels of any hormones than those who were in the lower half.

\section{Anthropometry and Leptin Levels}

By Chilean anthropometry standards, 9 of the 69 exposed offspring (13.0\%) were SGA compared with 5.7\% ( $p=0.03$ ) of the Chilean population (Ministry of Health of Chile 2004). The comparison was made with the birth weight of the most recent national Chilean standards since by experimental design our control children could not be SGA. The data on weight and height of ethanol- 


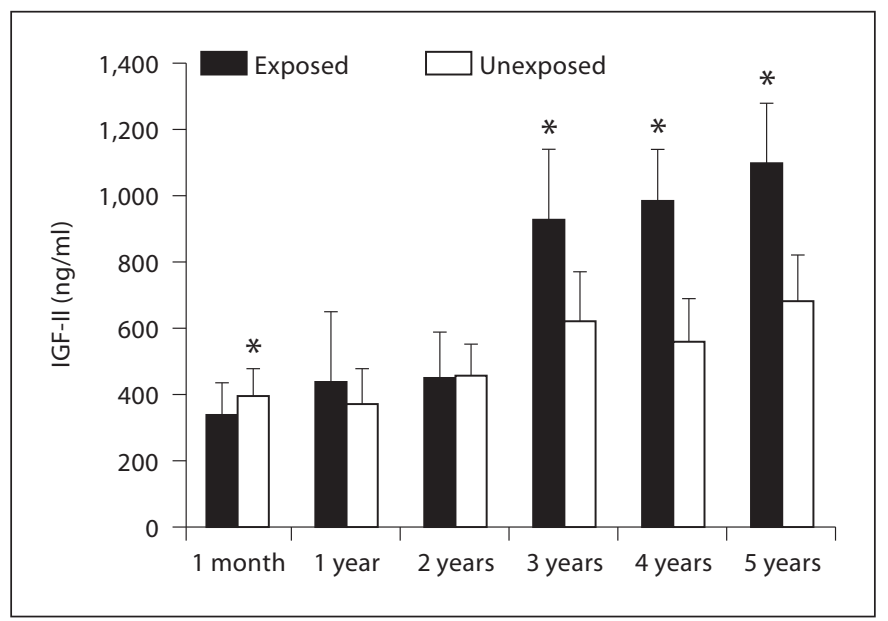

Fig. 1. IGF-II levels in ethanol-exposed and unexposed children. ${ }^{*} \mathrm{p}<0.001$.

exposed and unexposed children from 1 month to 5 years of age are shown in table 1 . Despite the fact that the control population was chosen to be AGA at birth to provide normal ranges for laboratory values (healthy controls) and, therefore, might have been expected to have better postnatal growth than the exposed population, there were few differences. At 1 month, 2, 3 and 5 years old there were no significant differences in height or weight between ethanol-exposed and unexposed children. At 1 year, the weight $\mathrm{Z}$-scores of the exposed children were marginally lower than the weight $Z$-scores of the unexposed $(p=0.05)$, but height $Z$-scores did not differ significantly. The ethanolexposed children were significantly heavier than the unexposed children at 4 years of age.

\section{Growth Factors}

Analysis of IGF-II levels revealed several noteworthy points. Serum IGF-II levels increased with age in both groups, but were significantly higher in the ethanol-exposed children compared with the unexposed at 3,4 and 5 years of age (fig. 1). Examining all IGF-II values longitudinally, the levels of the exposed group were significantly different from those of the unexposed group $(\mathrm{p}=$ 0.005). Initially, they had lower levels than the unexposed group. Over time, however, their levels increased. In the longitudinal analysis, the exposed group showed a rise in IGF-II levels of $109.5 \mathrm{ng} / \mathrm{ml}$ per year over the unexposed group. Their rate of increase in IGF-II was very significantly higher than the rate in the unexposed group $(\mathrm{p}<$ $0.0001)$. It is also worth noting that girls showed a more rapid increase than boys $(\mathrm{p}=0.015)$.
Table 1. Anthropometry and serum levels of growth factors and leptin in children exposed to ethanol in utero and unexposed children

\begin{tabular}{|c|c|c|c|}
\hline & $\begin{array}{l}\text { Exposed } \\
\text { mean } \pm S D\end{array}$ & $\begin{array}{l}\text { Unexposed } \\
\text { mean } \pm S D\end{array}$ & $\begin{array}{l}\mathrm{p} \text { values } \\
\text { (Wilcoxon) }\end{array}$ \\
\hline \multicolumn{4}{|l|}{1 month } \\
\hline $\mathrm{n}$ & 39 & 39 & \\
\hline Z-weight & $0.65 \pm 1.17$ & $0.59 \pm 1.17$ & NS \\
\hline Z-length & $0.17 \pm 0.98$ & $0.07 \pm 0.97$ & NS \\
\hline $\mathrm{BMI}$ & $15.81 \pm 1.91$ & $16.10 \pm 1.98$ & NS \\
\hline IGFBP-3 & $1.68 \pm 0.45$ & $1.83 \pm 0.37$ & NS \\
\hline Leptin & $6.77 \pm 7.64$ & $8.13 \pm 5.90$ & NS \\
\hline \multicolumn{4}{|l|}{1 year } \\
\hline $\mathrm{n}$ & 44 & 23 & \\
\hline Z-weight & $-0.13 \pm 1.11$ & $0.60 \pm 1.38$ & 0.05 \\
\hline Z-height & $-0.53 \pm 1.14$ & $-0.18 \pm 1.05$ & NS \\
\hline $\mathrm{BMI}$ & $17.55 \pm 1.78$ & $18.82 \pm 2.14$ & 0.02 \\
\hline IGFBP-3 & $1.65 \pm 0.54$ & $1.71 \pm 0.71$ & NS \\
\hline Leptin & $4.97 \pm 8.58$ & $6.41 \pm 5.22$ & 0.03 \\
\hline \multicolumn{4}{|l|}{2 years } \\
\hline $\mathrm{n}$ & 33 & 19 & \\
\hline Z-weight & $0.45 \pm 0.97$ & $0.79 \pm 1.12$ & NS \\
\hline Z-height & $0.15 \pm 0.98$ & $-0.02 \pm 0.91$ & NS \\
\hline BMI & $16.79 \pm 1.50$ & $17.65 \pm 1.25$ & 0.08 \\
\hline IGFBP-3 & $2.28 \pm 0.62$ & $2.42 \pm 0.67$ & NS \\
\hline Leptin & $2.52 \pm 1.33$ & $7.34 \pm 4.60$ & $<0.0001$ \\
\hline \multicolumn{4}{|l|}{3 years } \\
\hline $\mathrm{n}$ & 26 & 14 & \\
\hline Z-weight & $0.31 \pm 1.03$ & $0.39 \pm 1.08$ & NS \\
\hline Z-height & $-0.004 \pm 0.87$ & $-0.35 \pm 0.91$ & NS \\
\hline BMI & $17.08 \pm 1.97$ & $16.73 \pm 0.97$ & NS \\
\hline IGFBP-3 & $1.80 \pm 0.54$ & $1.63 \pm 0.56$ & NS \\
\hline Leptin & $5.22 \pm 3.48$ & $3.57 \pm 2.19$ & NS \\
\hline \multicolumn{4}{|l|}{4 years } \\
\hline $\mathrm{n}$ & 23 & 7 & \\
\hline Z-weight & $0.77 \pm 1.06$ & $-0.26 \pm 1.03$ & 0.03 \\
\hline Z-height & $0.22 \pm 1.00$ & $-0.11 \pm 0.86$ & NS \\
\hline BMI & $16.88 \pm 1.32$ & $15.41 \pm 1.67$ & 0.04 \\
\hline IGFBP-3 & $2.09 \pm 0.45$ & $1.69 \pm 0.53$ & NS \\
\hline Leptin & $5.80 \pm 4.17$ & $6.09 \pm 6.31$ & NS \\
\hline \multicolumn{4}{|l|}{5 years } \\
\hline $\mathrm{n}$ & 16 & 11 & \\
\hline Z-weight & $1.01 \pm 1.37$ & $0.45 \pm 1.56$ & NS \\
\hline Z-height & $0.11 \pm 0.85$ & $-0.21 \pm 1.01$ & NS \\
\hline BMI & $17.22 \pm 2.32$ & $16.59 \pm 2.12$ & NS \\
\hline IGFBP-3 & $2.29 \pm 0.51$ & $2.24 \pm 0.72$ & NS \\
\hline Leptin & $4.99 \pm 4.11$ & $12.04 \pm 12.26$ & NS \\
\hline
\end{tabular}

Z-weight = Correlation between IGF-I and IGF-II and weight Z-score; Z-height = correlation between IGF-I and IGF-II and height $\mathrm{Z}$-score; $\mathrm{BMI}=$ body mass index. 
Table 2. Correlations between IGF-I and IGF-II and weight Zscore (Z-weight), length/height Z-score (Z-length) and body mass index (BMI) in alcohol-exposed and unexposed children by age (Spearman correlation coefficients)

\begin{tabular}{|c|c|c|c|c|c|c|}
\hline & \multicolumn{3}{|c|}{ IGF-I } & \multicolumn{3}{|c|}{ IGF-II } \\
\hline & $\mathrm{n}$ & $\mathrm{r}$ & $\mathrm{p}$ & $\mathrm{n}$ & $\mathrm{r}$ & $\mathrm{p}$ \\
\hline \multicolumn{7}{|l|}{$\begin{array}{l}\text { Alcohol exposed } \\
1 \text { month }\end{array}$} \\
\hline & \multirow[t]{3}{*}{38} & 0.36 & 0.03 & \multirow[t]{3}{*}{38} & -0.12 & 0.46 \\
\hline Z-length & & -0.02 & 0.89 & & -0.06 & 0.73 \\
\hline Z-weight & & 0.23 & 0.16 & & -0.12 & 0.47 \\
\hline \multicolumn{7}{|l|}{1 year } \\
\hline BMI & \multirow[t]{3}{*}{44} & 0.27 & 0.08 & \multirow[t]{3}{*}{45} & 0.28 & 0.07 \\
\hline Z-length & & -0.03 & 0.87 & & -0.01 & 0.96 \\
\hline Z-weight & & 0.31 & 0.04 & & 0.31 & 0.04 \\
\hline \multicolumn{7}{|l|}{2 years } \\
\hline BMI & \multirow[t]{3}{*}{33} & 0.08 & 0.66 & \multirow[t]{3}{*}{33} & 0.07 & 0.69 \\
\hline Z-length & & 0.29 & 0.10 & & 0.20 & 0.26 \\
\hline Z-weight & & 0.24 & 0.18 & & 0.17 & 0.34 \\
\hline \multicolumn{7}{|l|}{3 years } \\
\hline BMI & \multirow[t]{3}{*}{25} & 0.27 & 0.18 & \multirow[t]{3}{*}{26} & -0.06 & 0.75 \\
\hline Z-height & & 0.14 & 0.51 & & 0.32 & 0.11 \\
\hline Z-weight & & 0.39 & 0.06 & & 0.24 & 0.24 \\
\hline \multicolumn{7}{|l|}{4 years } \\
\hline BMI & \multirow[t]{3}{*}{23} & 0.27 & 0.21 & \multirow[t]{3}{*}{26} & 0.11 & 0.61 \\
\hline Z-height & & 0.26 & 0.24 & & 0.13 & 0.54 \\
\hline Z-weight & & 0.43 & 0.04 & & 0.13 & 0.52 \\
\hline \multicolumn{7}{|l|}{5 years } \\
\hline BMI & \multirow[t]{3}{*}{16} & 0.31 & 0.25 & \multirow[t]{3}{*}{17} & 0.12 & 0.63 \\
\hline Z-height & & -0.12 & 0.67 & & -0.07 & 0.78 \\
\hline Z-weight & & 0.17 & 0.54 & & -0.04 & 0.87 \\
\hline \multicolumn{7}{|c|}{$\begin{array}{l}\text { Alcohol unexposed } \\
1 \text { month }\end{array}$} \\
\hline $\begin{array}{l}\text { I month } \\
\text { BMI }\end{array}$ & 39 & 0.16 & 0.34 & 39 & 0.32 & 0.05 \\
\hline Z-length & & 0.06 & 0.72 & & 0.10 & 0.54 \\
\hline Z-weight & & -0.01 & 0.97 & & 0.10 & 0.56 \\
\hline 1 year & & & & & & \\
\hline BMI & 23 & 0.17 & 0.44 & 23 & 0.32 & 0.14 \\
\hline Z-length & & 0.56 & 0.01 & & 0.38 & 0.07 \\
\hline Z-weight & & 0.50 & 0.01 & & 0.49 & 0.02 \\
\hline 2 years & & & & & & \\
\hline BMI & 17 & 0.60 & 0.01 & 17 & 0.34 & 0.18 \\
\hline Z-length & & 0.35 & 0.16 & & 0.02 & 0.94 \\
\hline Z-Wweight & & 0.65 & 0.005 & & 0.23 & 0.38 \\
\hline 3 years & & & & & & \\
\hline BMI & 13 & 0.57 & 0.04 & 13 & 0.34 & 0.25 \\
\hline Z-height & & 0.67 & 0.01 & & 0.13 & 0.67 \\
\hline Z-weight & & 0.60 & 0.03 & & 0.19 & 0.54 \\
\hline 4 years & & & & & & \\
\hline BMI & 7 & 0.68 & 0.09 & 7 & 0.49 & 0.27 \\
\hline Z-height & & 0.04 & 0.94 & & 0.09 & 0.85 \\
\hline Z-weight & & 0.68 & 0.09 & & 0.49 & 0.27 \\
\hline 5 years & & & & & & \\
\hline BMI & 11 & 0.47 & 0.14 & 11 & 0.65 & 0.03 \\
\hline Z-height & & 0.70 & 0.02 & & 0.53 & 0.09 \\
\hline Z-weight & & 0.67 & 0.02 & & 0.66 & 0.03 \\
\hline
\end{tabular}

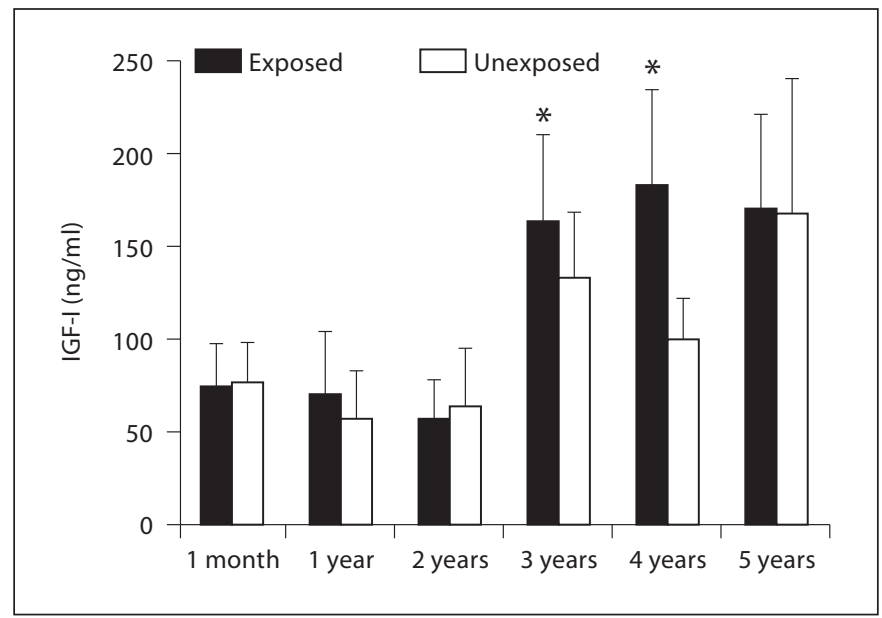

Fig. 2. IGF-I levels in ethanol-exposed and unexposed children. ${ }^{*} \mathrm{p}<0.05$.

Serum IGF-I levels were significantly higher in ethanol-exposed compared with unexposed children at 3 and 4 years of age (fig. 2). As shown in table 1, serum IGFBP-3 levels in ethanol-exposed children were not significantly different from levels in the unexposed. Leptin levels were significantly lower at 1 and 2 years of age, but the differences did not persist at older ages.

Poor nutrition cannot account for our findings. Of the 188 time points at which hormone data were collected, data on nutritional status were available for 181 . On only 6 occasions (3.3\%) was the child considered possibly undernourished. No subject was considered undernourished on more than one occasion.

There were no significant correlations between hormone levels and change in height or weight between ages 1 and 2 with one exception: IGF-II levels at 2 years of age and change in height were significantly correlated $(\mathrm{r}=$ $0.50, \mathrm{p}=0.03)$ in the exposed group. The number of observations, however, was small.

Table 2 shows the correlations between growth measures and IGF-I and IGF-II in the alcohol-exposed and unexposed groups by age. As expected, the unexposed group showed a strong correlation between weight, height and body mass index and IGF-I. At many ages, the correlations were statistically significant despite the modest numbers. Also, as expected, there was a weaker positive correlation between the growth measures and IGF-II (4 of 18 reached statistical significance). In the alcohol-exposed group, in contrast, the correlation between IGF-I and the growth measures was lower and rarely reached statistical significance. For IGF-II, the correlation was 
generally lower than in the unexposed group as well and only the 1-year correlation with weight was statistically significant.

The group of 3 exposed children with FAS was too small to analyze separately. We conducted a secondary analysis excluding them. The one noteworthy change was that the percentage of exposed children born SGA fell to $12.1 \%$ and was no longer significantly higher than the expected rate in the Chilean population $(\mathrm{p}=0.07)$. The comparisons between the hormone levels in the exposed and unexposed did not change significantly.

\section{Discussion}

This study has investigated the effects of prenatal ethanol exposure on serum growth factors in humans, where current knowledge is very limited.

In a previous report, a small group of short children with FAS exhibited serum IGF- I and IGFBP-3 in the low normal range [9], and it has been suggested that newborn infants of ethanol-abusing mothers may have low serum IGF-I levels [10]. Interestingly, in our much larger, prospective study, we observed that serum IGF-I and IGF-II levels increased during postnatal life in children exposed to ethanol in utero compared with healthy unexposed children. This was particularly true for serum IGF-II levels. IGF-II levels were weakly correlated with growth measures in the children, which may not be surprising given that IGF-II appears to be more important for prenatal growth. IGF-I was correlated more strongly and more significantly in the unexposed than in the exposed group, suggesting that alcohol disturbs the normal relationship.

Our exposed subjects were more likely to be SGA at birth than the general Chilean population. This effect did not persist. Although some studies show persistent poor growth in children exposed to large quantities of alcohol in utero, others do not [6]. It appears that children who are reasonably well nourished can experience catch-up growth. Our population was lower middle class, not impoverished, and most had good diets. Thus, it is likely that they did experience catch-up growth and grew reasonably well since most of them did not manifest the classic FAS phenotype.

The IGF system is very important for pre- and postnatal growth. Both IGF-I and IGF-II are detected in the fetal circulation during early gestation, but their specific actions differ depending on the fetal tissue and gestational age. There is a known association of IGF-I serum levels with birth weight, ponderal index and birth length [25, 26], and its effects are regulated by nutrient supply.

Altered prenatal expression of these growth factors and/or its receptor may influence fetal growth. IGF-I gene polymorphisms have been associated with reduced birth size, and IGF-I receptor mutations have also been found in patients with intrauterine growth restriction [27, 28]. Experiments in knockout mice have shown the importance of IGFs for fetal growth, since gene deletions for IGF-I and IGF-II are associated with a birth weight approximately $40 \%$ below that of the wild type [29]. From human studies, it is known that IGF-I gene deletions or mutations may cause intrauterine growth restriction $[30$, 31].

IGF-II is the primary growth factor supporting prenatal growth, but most studies have not documented an association with birth weight [32]. IGFs, especially IGF-II, may influence placental function [33], and reduced placental expression of IGF-II is associated with intrauterine growth restriction [12]. Serum concentrations of IGF-II are much higher than those of IGF-I during late gestation, and tissue and circulating IGF-II concentrations are higher in the fetus than in the newborn or adult in most species. Likewise, there is a shift in IGF predominance from IGF-II during gestation to IGF-I after birth. Serum IGF-II concentrations are relatively unaffected by variations in nutritional status, but they are modified by changes in fetal glucocorticoid concentrations, suggesting that they may be affected by adverse intrauterine conditions [34]. This growth factor may play a role in normal growth, as Bernardini et al. [35] demonstrated that there is a progressive increase in serum IGF-II levels during the first 3 months of life in normal infants, and García et al. [36] reported a transient increase in serum IGF-II at 3 months of age in SGA infants who experienced catch-up growth.

Very limited data are available regarding the serum concentrations of these hormones in human fetuses exposed to alcohol during pregnancy. Mauceri et al. [37] showed that ethanol alters the pattern of IGF-II release in rat fetuses, probably by interference with the signaling mechanism. During gestation, control rats had increased tissue release of IGF-II, especially in the brain; but in ethanol-exposed rats the IGF-II content in specific tissues was not increased. Systemic IGF-II levels were elevated, which may reflect IGF-II release from the liver or a slower clearance. Whether IGF-II plays a role in ethanol-induced brain dysfunction is not clear [37]. In addition, in agreement with our findings, Gundogan et al. [12] recently demonstrated that prenatal exposure to ethanol in 
rodents increases placental IGF-II concentrations and IGF-II receptor mRNA levels. However, Singh et al. [38] showed reduced IGF-II mRNA and serum levels in a fetal rodent model exposed to ethanol.

We found that children exposed to large amounts of alcohol prenatally, particularly girls, start with lower than expected IGF-II levels in infancy, but their levels increase very rapidly in early childhood to become significantly higher during the first few years of life. These findings in children exposed prenatally to high amounts of ethanol should prompt investigation of serum IGF-II as a potential marker for prenatal alcohol exposure. In conjunction with other data, it could potentially be a valuable marker of ethanol exposure in suspected cases in which a clear maternal history is not available.

Leptin is an adipocyte-secreted hormone, present in higher concentrations in females, which is significantly associated with newborn weight and length [39, 40]. In children at high risk for adult obesity, high baseline serum leptin concentration predicts greater body mass index and fat mass over time in both genders [41]. Prenatal ethanol exposure results in decreased leptin levels in subcutaneous adipose tissue of neonatal rats, but not in adult rats [42]. We observed lower serum leptin levels at 1 and 2 years of age in our ethanol-exposed children, which may be explained by prenatal ethanol exposure.

This study has several strengths, such as the fact that ethanol exposure was documented prenatally in a large cohort of women who came from an unselected population attending a prenatal clinic, and the exposed children were followed longitudinally over time. The study has limitations as well. Although only a small number of subjects were born early enough in the study to be followed to age 5 , and the small sample size decreases the power to find differences, we were able to identify significant dif- ferences between the exposed and unexposed groups. As noted above, we had to use an external control group to provide reference data for logistic reasons. In fact, the potential problem that choosing healthy children could have made the exposed group's growth look worse by comparison turned out not to be the case. The very limited number of control subjects who provided data at more than one time point is, nonetheless, a limitation of the study.

As expected in an unselected group of children heavily exposed to alcohol prenatally, most of them did not develop full blown FAS. This may explain the limited impact that this exposure had on longitudinal growth and serum IGF-I and IGFBP-3 levels, although it is noteworthy that the normal correlation between IGF-I and growth parameters was greatly reduced in our exposed population.

Growth retardation is one of the defining features of FAS; however, the etiology of growth retardation in FAS remains unclear. Our population, which was exposed to large quantities of alcohol in utero, showed increased serum IGF-I and IGF-II levels during early childhood. In addition, we observed that ethanol-exposed children showed lower leptin levels at 2 years, which may be caused by effects of ethanol on adipose tissue. The high concentration of serum IGF-II in the ethanol-exposed children suggests that this hormone should be further investigated as a marker for prenatal alcohol exposure.

\section{Acknowledgment}

This study was funded by the Intramural Research Program, Eunice Kennedy Shriver National Institute of Child Health and Human Development, National Institutes of Health, USA.

\section{References}

1 Stratton K, Howe C, Battaglia F (eds): Fetal Alcohol Syndrome: Diagnosis, Epidemiology, Prevention and Treatment. Washington, National Academy Press, 1996.

$\checkmark 2$ Day NL, Jasperse D, Richardson G, Robles N, Sambamoorthi U, Taylor P, Scher M, Stoffer D, Cornelius M: Prenatal exposure to alcohol: effect on infant growth and morphologic characteristics. Pediatrics 1989;84:536541.

3 Day NL, Zuo Y, Richardson G, Goldschmidt L, Larkby C, Cornelius M: Prenatal alcohol use and offspring size at 10 years of age. Alcohol Clin Exp Res 1999;23:863-869.
4 Aufrère G, Le Bourhis: Effect of alcohol intoxication during pregnancy on foetal and placental weight: experimental studies. Alcohol Alcohol 1987;22:401-407.

$\checkmark 5$ Day NL, Leech SL, Richardson GA, Cornelius MD, Robles N, Larkby C: Prenatal alcohol exposure predicts continued deficits in offspring size at 14 years of age. Alcohol Clin Exp Res 2002;26:1584-1591.

6 Day NL, Richardson GA: An analysis of the effects of prenatal alcohol exposure on growth: a teratologic model. Am J Med Genet C Semin Med Genet 2004;127C:28-34.
7 Tze WJ, Friesen HG, Mac Leod PM: Growth hormone response in fetal alcohol syndrome. Arch Dis Child 1976;51:703-706.

$>8$ Castells S, Mark E, Abaci F, Schwartz E: Growth retardation in fetal alcohol syndrome: unresponsiveness to growth-promoting hormones. Dev Pharmacol Ther 1981;3:232-241.

9 Hellstrom A, Jansson C, Boguszewski M, Olegard R, Laegreid L, Albertsson-Wikland $\mathrm{K}$ : Growth hormone status in six children with fetal alcohol syndrome. Acta Paediatr 1996;85:1456-1462. 
10 Halmesmaki E, Valimaki M, Karonen SL, Ylikorkala O: Low somatomedin $\mathrm{C}$ and high growth hormone levels in newborns damaged by maternal alcohol abuse. Obstet Gynecol 1989;74(3 pt 1):366-370.

- 11 Woods KA, Van Helvoirt M, Ong K, Mohn A, Levy J, De Zegher F, Dunger DB: The somatotropic axis in short children born small for gestational age: relation to insulin resistance. Pediatr Res 2002;51:76-80.

-12 Gundogan F, Elwood G, Longato L, Tong M, Feijoo A, Carlson RI, Wands JR, de la Monte SM: Impaired placentation in fetal alcohol syndrome. Placenta 2008;29:148-157.

- 13 Breese CR, D’Costa A, Ingram RL, Lenham J, Sonntag WE: Long-term suppression of insulin-like growth factor-1 in rats after in utero ethanol exposure: relationship to somatic growth. J Pharmacol Exp Ther 1993;264: 448-456.

-14 Breese CR, Sonntag WE: Effect of ethanol on plasma and hepatic insulin-like growth factor regulation in pregnant rats. Alcohol Clin Exp Res 1995; 19:867-873.

-15 Mauceri HJ, Unterman T, Dempsey S, Lee W, Conway S: Effect of ethanol exposure on circulating levels of insulin-like growth factors I and II, and insulin-like growth factors binding proteins in fetal rats. Alcohol Clin Exp Res 1993;17:1201-1206.

-16 Kumar V, Silvis C, Nystrom G, Deshpande M, Vary TC, Frost RA, Lang CH: Alcoholinduced increases in insulin-like growth factor binding protein-1 are partially mediated by TNF. Alcohol Clin Exp Res 2002;26:15741583.

17 Calissendorff J, Brismar K, Röjdmark S: Is decreased leptin secretion after alcohol ingestion catecholamine-mediated? Alcohol Alcohol 2004;39:281-286.

18 National Center on Birth Defects and Developmental Disabilities, Centers for Disease Control and Prevention, Department of Health and Human Services: Fetal Alcohol Syndrome: Guidelines for Referral and Diagnosis. Atlanta,2004.

-19 Abel EL, Kruger ML, Friedl J: How do physicians define 'light', 'moderate' and 'heavy' drinking? Alcohol Clin Exp Res 1998;22: 979-984.

-20 Aros S, Mills JL, Torres C, Henríquez C, Fuentes A, Capurro T, Mena M, Conley M, Cox C, Signore C, Klebanoff M, Cassorla F: Prospective identification of pregnant women drinking four or more standard drinks ( $\geq 48 \mathrm{~g}$ ) of alcohol per day. Subst Use Misuse 2006;41:183-197.

-21 Juez G, Lucero E, Ventura-Junca P, González $\mathrm{H}$, Tapia JL, Winter A: Intrauterine growth in Chilean middle class newborn infants. Rev Chil Pediatr 1989;60:198-202.
22 Iñiguez G, Ong K, Bazaes R, Avila A, Salazar T, Dunger D, Mericq V: Longitudinal changes in IGF-I, insulin sensitivity and secretion from birth to age three years in small-forgestational-age children. J Clin Endocrinol Metab 2006;91:4645-4649.

23 Iñiguez G, Salazar T, Roman R, Avila A, Gunn RD, Cassorla F: Effects of the IGF-I/ IGFBP-3 complex over GH and ghrelin nocturnal concentrations in low birth weight children. Clin Endocrinol (Oxf) 2006;65: 687-692.

24 Iñiguez G, Soto N, Avila A, Salazar T, Ong K Dunger D, Mericq V: Adiponectin levels in the first two years of life in a prospective cohort: relations with weight gain, leptin levels and insulin sensitivity. J Clin Endocrinol Metab 2004;89:5500-5503.

-25 Skalkidou A, Petridou E, Papathoma E, Salvanos H, Kedikoglou S, Chrousos G, Trichopoulus D: Determinants and consequences of major insulin-like growth factor components among full-term healthy neonates. Cancer Epidemiol Biomarkers Prev 2003;12: 860-865.

26 Boyne MS, Thame M, Bennett FI, Osmond C, Miell JP, Forrester TE: The relationship among circulating insulin-like growth factor (IGF)-I, IGF-binding proteins-1 and -2 , and birth anthropometry: a prospective study. J Clin Endocrinol Metab 2003;88: 1687-1691.

-27 Abuzzahab MJ, Schneider A, Goddard A, Grigorescu F, Lautier C, Keller E, Kiess W, Klammt J, Kratzsch J, Osgood D: IGF-I receptor mutations resulting in intrauterine and postnatal growth retardation. N Engl J Med 2004;349:2211-2222.

28 Walenkamp MJE, van der Kamp HJ, Pereira AM, Kant SG, van Duyvenvoorde HA, Kruithof MF, Breuning MH, Romijn JA, Karperien M, Wit JM: A variable degree of intrauterine and postnatal growth retardation in a family with a missense mutation in the insulin-like growth factor I receptor. J Clin Endocrinol Metab 2006;91:3062-3070.

29 Arends N, Johnston LB, Hokken-Koelega A, Van Duin C, De Ridder M, Savage M, Clark A: Polymorphism in the IGF-I gene: clinical relevance for short children born small for gestational age (SGA). J Clin Endocrinol Metab 2002;87:2720-2724.

30 Woods KA, Camacho-Hübner C, Savage MO, Clark AJ: Intrauterine growth retardation and postnatal growth failure associated with deletion of the insulin-like growth factor I gene. N Engl J Med 1996;335:1389-1391.
31 Walenkamp MJ, Karperien M, Pereira AM, Hilhorst-Hofstee Y, van Doorn J, Chen JW, Mohan S, Denley A, Forbes B, van Duyvenvoorde $\mathrm{HA}$, van Thiel SW, Sluimers CA, Bax JJ, de Laat JA, Breuning MB, Romijn JA, Wit JM: Homozygous and heterozygous expression of a novel insulin-like growth factor-I mutation. J Clin Endocrinol Metab 2005;90: 2855-2864.

32 Gicquel C, Le Bouc Y: Hormonal regulation of fetal growth. Horm Res 2006;65(suppl 3):28-33

33 Han VK, Carter AM: Spatial and temporal patterns of expression of messenger RNA for insulin-like growth factors and their binding proteins in the placenta of man and laboratory animals. Placenta 2000;21:289-305.

$\$ 34$ Fowden AL: The insulin-like growth factors and feto-placental growth. Placenta 2003;24: 803-812.

-35 Bernardini B, Spandoni GL, Povoa G, Boscherini B, Hall K: Plasma levels of insulin-like growth factor binding protein-I and growth hormone binding protein activity from birth to the third month of life. Acta Endocrinol 1992;127:313-318.

-36 García H, Henríquez C, Ugarte F, Fernández E, Beas F, Iñiguez G, Boric A, Pizarro F, Cassorla F: GH-IGF Axis during catch up growth in small for gestational age (SGA) infants. J Pediatr Endocrinol Metab 1996;9:561-567.

$\checkmark 37$ Mauceri HJ, Lee WH, Conway S: Effect of ethanol on insulin-like growth factor-II release from fetal organs. Alcohol Clin Exp Res 1994;18:35-41.

>38 Singh SP, Srivenugopal KS, Ehmann S, Yuan $\mathrm{XH}$, Snyder AK: Insulin-like growth factors (IGF-I and IGF-II), IGF-binding proteins, and IGF gene expression in the offspring of ethanol-fed rats. J Lab Clin Med 1994;124: 183-192.

39 Petridou E, Mantzoros CS, Belechri M, Skalkidou A, Dessypris N, Papathoma E, Salvanos H, Lee JH, Kedikoglou S, Chrousos G, Trichopoulos D: Neonatal leptin levels are strongly associated with female gender, birth length, IGF-I levels and formula feeding. Clin Endocrinol (Oxf) 2005;62:366-371.

40 Kratzsch J, Schubring C, Stitzel B, Böttner A, Berthold A, Thiery J, Kiess W: Inverse changes in the serum levels of the soluble leptin receptor and leptin in neonates: relations to anthropometric data. J Clin Endocrinol Metab 2005;90:2212-2217.

41 Fleisch AF, Agarwal N, Roberts MD, Han JC, Theim KR, Vexler A, Troendle J, Yanovski SZ, Yanovski JA: Influence of serum leptin on weight and body fat growth in children at high risk for adult obesity. J Clin Endocrinol Metab 2007;92:948-954.

42 Chen L, Nyomba BL: Effects of prenatal alcohol exposure on glucose tolerance in the rat offspring. Metabolism 2003;52:454-462. 